УДК 94(477) “1918/1924”

DOI: 10.31651/2413-8142-2019-22-20-24

O. Kompaniiets

post-graduate student of the Department of Archeology and Auxiliary sciencies of history of the Bohdan Khmelnytsky National University of Cherkasy ORCID: https://orcid.org/0000-0001-6239-3039

A. Morozov

Doctor of history, Professor, Professor of the Department of Archeology and Auxiliary sciences of history of the Bohdan Khmelnytsky National University of Cherkasy ORCID: https://orcid.org/0000-0001-5486-235X

\section{COLLECTIVE BIOGRAPHY OF THE LEADERS OF THE RURAL REBELLION MOVEMENT OF MIDDLE DNIPRO REGION (1918 - 1920'S)}

There is the first attempts to write a collective portrait of the otamans of the Middle Dnipro region, who were the leader of the rural rebel movement at this land during the Ukrainian National Revolution of 1917 - 1921. The authors of the article summarize the results of the predecessors in the study of the activities of individual otamans in order to identify certain trends and patterns of the insurgent movement, which at first glance seems spontaneous and chaotic. The collective portrait is based on the biographies of 22 otamans, namely such aspects as: their place of birth, age, education, profession, military experience (including participation in World War I), the time of the beginning and the end of the rebel struggle, political orientation and further destiny.

Key words: collective biography, collective portrait, prosopographic analysis, rural rebel movement, "otamans», "otamanshchyna», Middle Dnipro region, Ukrainian National Revolution 1917 - 1921

Problem statement. For the national historiography of the independence period, the topic of the insurgent movement became so popular that we have sufficient reason to distinguish it as a separate line of studies on the history of the Ukrainian National Revolution of 1917 1921. With hundreds of bibliographical items, the rural rebel movement as scientific problem looks fairly well studied. However, moving away from popular descriptive and generalizing methods in favor of highly specialized can be promising, even regarding seemingly well-studied issues.

Research analysis. At present, historiography does not attempt to create a collective portrait of the leaders of the peasant rebel movement during the Ukrainian National Revolution of 1917 - 1921. Instead, there are a considerable number of publications devoted to the activities of individual otamans, which, however, often spread contradictory and precisely unconfirmed information, historical myths about their life.

The studies of such contemporary historians as D. Arxiyerejs'ky'j [1], O. Ganzha [2], A. Demartino [6], P. Isakov [1], D. Krasnosiletsky [1], Yu. Mitrofanenko [11]. V. Reveguk [14], V. Reznikov [1], V. Shcherbatiuk [17] are directly or tangentially related to the personal measurement of the rural rebel movement.

The local historian R. Koval [8; 9] prepared many biographical essays about the otamans of the Middle

* The article is written in accordance with the state budget theme "Ukrainian Revolution (1917-1921 gg.): The peasant factor" (state registration number 0118U003864).
Dnipro region. On the one hand, he returned from oblivion the names of many leaders of the rural rebel movement, but on the other, R. Koval's researches remains unrecognized by historians due to lack of expertise and artistic thinking.

A lot of new information, including archival documents on the lives and activities of the rebel otamans, is contained in the book series «Rehabilitated by History» [13].

The activities of the Middle Dnipro region otamans did not find sufficient reflection on the pages of the tenvolume «Encyclopedia of History of Ukraine», - the most fundamental since the independence of the reference edition on the history of Ukraine. Thus, it is found only articles about rebel leaders such as Ivan Lyuty'jLyutenko [9, 397], Yakiv Vodyany'j [15, 592], Semen Gry'zlo[16, 202].

The purpose of publication is to identify, using the method of «collective biographies», the previously unknown patterns and trends that have occurred among the leaders of the insurgency in the Middle Dnipro in 1918 - early 1920.

The statement of the basic material. In historical science, prosopography, as a rule, refers to the method of creating collective biographies, which allows to obtain a description of the most typical historical actors, to identify and define a certain circle of persons as types that personify certain processes and events $[12,417-$ 419].

It should be noted, that the term «rebel otamans» sometimes has a blurred meaning and suffers from the mechanical attribution of «otamanical» status to some actors.

It should also be made several remarks concerning the criteria and principles of sampling: it does not include some insurgent leaders who acted in the Middle Dnipro region only casually, about which is very little information or reliability is doubtful. Thus, without attention were the otamans Nezbiyenko, Tereshhenko, Chorny'j voron (Yakiv Chernousov?), Chornota (Yurij Drobotkovs'ky'j ?) and others.

The biographies of 22 rebel leaders were the objects of prosopographic analysis:

Babenko Troxy'm Ivanovy'ch, Vodyany'j Yakiv My'xajlovy'ch, Gladchenko Try' fon Fedorovy'ch, Goly'k-Zaliznyak Mefodij Foky'ch, Gry'zlo Semen Gry'gorovy'ch, Gupalo Deny's Musijovy'ch, Dereshhuk Petro Kuz'movy'ch, Derkach Ivan Ty'mofijovy'ch, Zavgorodnij Ilarion Zaxarovy'ch, Kvasha Vasy'l' My'ronovy'ch, Keleberda Panas Dmy'trovy'ch, Kibecz'-Bondarenko My'kola Stepanovy'ch, Lyuty'jLyutenko Ivan Makarovy'ch, Nesterenko Gerasy'm Onufrijovy'ch, Petrenko Ivan, Savchenko (SavchenkoNagirny'j) Ivan Gry'gorovy'ch, Filonenko Semen Dmy'trovy'ch, Xmara Py'ly'p Panasovy'ch, Czvitkovs'ky'j Dmy'tro, Chuchupak Vasy'l' Stepanovy'ch, Chuchupak Oleksa Stepanovy'ch, Chuchupak Petro Stepanovy'ch.

An age.

Taking into account the age from which the abovementioned leaders joined to the rebellion movement, an average age of 26.7 years was obtained. Among the youngest otamans are Troxy'm Babenko and Larion Zavgorodnij (21 years old); the oldest are Petro Dereshhuk and Petro Chuchupak (they started a rebellious struggle at the age of 34). 
Origin and the area of active rebel struggle.

In view of the area where the rebel movement was launched, $95.5 \%$ of the otamans can be considered as local. Thus, only Try'fon Gladchenko was born in present Dnipro oblast (district). 14 persons (64\%) were natives of the present Cherkasy oblast (district), and 7 persons - of the present Kirovohrad oblast (district). Accordingly, the activities of the first were concentrated mainly in the north and central, and of the second - in the southern part of the Xolodny'j Yar (The Cold Ravine forest massive). It should be noted, that 16 of the 22 otamans $(72.7 \%)$ wholly or partially operated at the territory of the same uyezd (county) as they came from.

Profession, professional affiliation.

Among the 22 otamans managed to find information about the profession of half of them. Thus, among the 11 people we meet only one professional military (Ivan Lyuty'j-Lyutenko). Mefodij Goly'k-Zaliznyak worked before rebel struggle at railway station, and 9 out of 11 future otamans were teachers by profession (Yakiv Vodyany'j, Petro Dereshhuk, Vasy'l', Oleksa i Petro Chuchupaky', Semen Gry'zlo, Troxy'm Babenko, Try'fon Gladchenko, Gerasy'm Nesterenko). The latter indicates that the intelligentsia finally managed to find a common language with the peasantry, becoming not only «their» but also gaining authority in the eyes of the peasants.

World War I experience.

The status of 19 of the 22 leaders of the insurgent movement is known. Among them, 16 (84.2\%) were veterans of the World War I. Among the rebel leaders who had combat experience, seven graduated from the ranks of chief officers: two staff captains (Petro Dereshhuk and Dmy'tro Czvitkovs'ky'j), one lieutenant (Trifon Gladchenko), four ensigns (Larion Zavgorodnij, Gerasy'm Nesterenko, Vasy'l' i Petro Chuchupak). Four leaders of the insurgent movement held the rank of noncommissioned officers (Py'ly'p Xmara, Troxy'm Babenko, Ivan Lyuty'j-Lyutenko, Semen Filonenko), and four others left the front in the rank of private or sailors (My'kola Kibecz'-Bondarenko, Ivan SavchenkoNagirny'j, Oleksa Chuchupak, Panas Keleberda). Otaman Vasy'l' Kvasha returned from the World War I with an officer rank, but it is not known exactly what his rank was. The future otamans Yakiv Vodyany'j and Deny's Gupalo were not mobilized during the war.

From this we can conclude that the presence of not only a large number of weapons carried by the peasantry from the front, but also significant combat experience, supported by the knowledge and organizational qualities of the otamans - often former officers and noncommissioned officers - provided stability, efficiency and tactical literacy of peasant rebellion movement.

The dynamics of the rise and fall of the insurgent movement. Duration of insurgency.

The average duration of otaman's insurgency was 29.4 months, that is, almost, 2.5 years. Detachments of some leaders of the insurgent movement were eliminated quickly: My'kola Kibecz'-Bondarenko's - for 4 months, Petro i Vasy'l' Chuchupak's - for 11 months, and Py'ly'p Xmara's - for a year. The probable reason for this is the particularly intense rebel movement led by the aforementioned figures. At the same time, the more nimble chieftains, or those who commanded smaller detachments, were more cautious and less active - lasting much longer. Thus, the detachment of Larion Zavgorodnij's fought during 47 months, Ivan Lyuty'j-
Lyutenko's and Petro Dereshhuk's-48 months each, Gerasy'm Nesterenko's - 49 months, and Yakiv Vodyany'j-during 60 months.

Table 1

The time of the beginning and ending of the struggle of the rebel otamans in the Middle Dnipro region

\begin{tabular}{|l|c|c|c|}
\hline \multicolumn{1}{|c|}{ Rebel otaman } & $\begin{array}{c}\text { The beginning } \\
\text { of rebel } \\
\text { struggle }\end{array}$ & $\begin{array}{c}\text { The ending of } \\
\text { rebel struggle }\end{array}$ & $\begin{array}{c}\text { Duration } \\
\text { (months) }\end{array}$ \\
\hline Vodyany`j Yakiv & March 1918 & Spring 1922 p. & 60 \\
\hline Goly`k-Zaliznyak Mefodij & February 1920 & September 1922 p. & 31 \\
\hline Dereshhuk Petro & 1920 & March 1924 p. & 48 \\
\hline Derkach Ivan & November 1919 & August 1921 p. & 32 \\
\hline Zavgorodnij Ilarion & November 1918 & September 1922 & 47 \\
\hline Kvasha Vasy`` & 1920 & 1922 & 36 \\
\hline Xmara Py`ly`p & May 1920 & May 1921 & 12 \\
\hline Keleberda Panas & 1919 & August 1920 & 20 \\
\hline Chuchupak Vasy`` & April 1919 & March 1920 & 11 \\
\hline Chuchupak Oleksa & February 1919 & August 1921 & 31 \\
\hline Chuchupak Petro & April 1919 & March 1920 & 11 \\
\hline Gry`zlo Semen & May 1919 & March 1921 & 23 \\
\hline Czvitkovs`ky`j Dmy`tro & February 1920 & July 1921 & 17 \\
\hline Petrenko Ivan & mid. 1920 & August 1921 & 13 \\
\hline Babenko Troxy`m & 1919 & December 1921 & 36 \\
\hline Savchenko-Nagirny`j Ivan & Autumn 1919 & February 1923 & 39 \\
\hline Filonenko Semen & June 1919 & November 1922 & 41 \\
\hline Gladchenko Try` fon & Autumn 1919 & late 1920 & 13 \\
\hline Lyuty`j-Lyutenko Ivan & Autumn 1919 & Autumn 1922 & 48 \\
\hline Nesterenko Gerasy`m & August 1919 & Autumn 1922 & 49 \\
\hline Kibecz`-Bondarenko My`kola & Autumn 1920 & January 1921 & 4 \\
\hline Gupalo Deny`s & September 1920 & September 1922 & 24 \\
\hline
\end{tabular}

Table 1 shows that the vast majority of otamans of the Middle Dnipro region embarked on the path of insurgent struggle during 1919-1920. Three major bursts of insurgent activity are clearly traced here: 1) FebruaryJune 1919 (5 otamans joined the insurgent movement); 2) August - November 1919 (5 new otamans started fighting); 3) the first half of 1920 (the appearance of 4 more otamans). For details, see Figure 1.

Figure 1.

The beginning of the participation of the otamans in the rebel movement in the Middle Dnipro region 
At the same time, it follows from Table 1 that the majority of the otamans ceased their participation in the insurgent movement during 1921 - 1922. One explanation for this trend is the decision of the $\mathrm{X}^{\text {th }}$ Congress of the Russian Communist Party (Bolsheviks) in March 1921 about the transition to a new economic policy and, at the same time, a series of ghostly amnesties for participants in the insurgent struggle. Thus, during March 1921 December 1922, the struggle was stopped by 15 of the 22 otamans. For details, see Figure 2.

Figure 2.

The time of otaman's departure from the rebel struggle at the Middle Dnipro region

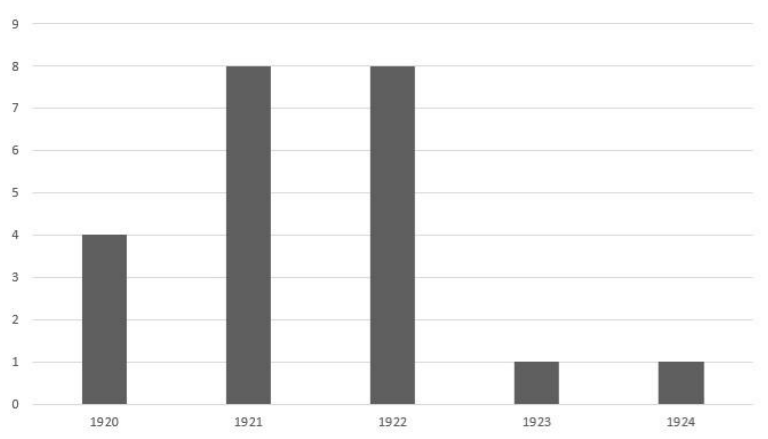

Circumstances of the otaman's departure from the rebel struggle.

Based on information about the fate of 21 of the 22 leaders of the insurgent movement (the exception is Trifon Gladchenko), it was possible to establish that only one otaman, Ivan Lyuty-Lyutenko, survived to the elderly and died of natural causes (in emigration - 1989, USA). In total, 3 of 22 otamans went to emigration escapeю But one of them, Yakiv Vodyany'j, was arrested by the NKVD in Western Ukraine in 1940 and was executed. Another emigrant, Gerasy'm Nesterenko, was arrested in 1944 by SMERSh officers in Romania and died in the Gulag prison camps.

Figure 3 shows that the circumstances of the cessation of the struggle by rebellion movement leaders were the next: $41 \%$ died in battles with the Red Army; or the Cheka (All-Russian Extraordinary Commission), 23\% were arrested and shot; $18 \%$ believed in Bolshevik amnesty and laid down their weapons, after which they were executed; $9 \%$ emigrated, but were later arrested by Soviet security agencies; $4 \%$ emigrated and remained safe; the fate of $5 \%$ of the щtamans remains unknown.

Figure 3.

The further fate of the leaders of the rebel movement in the Middle Dnipro region in 1918 - early 1920's

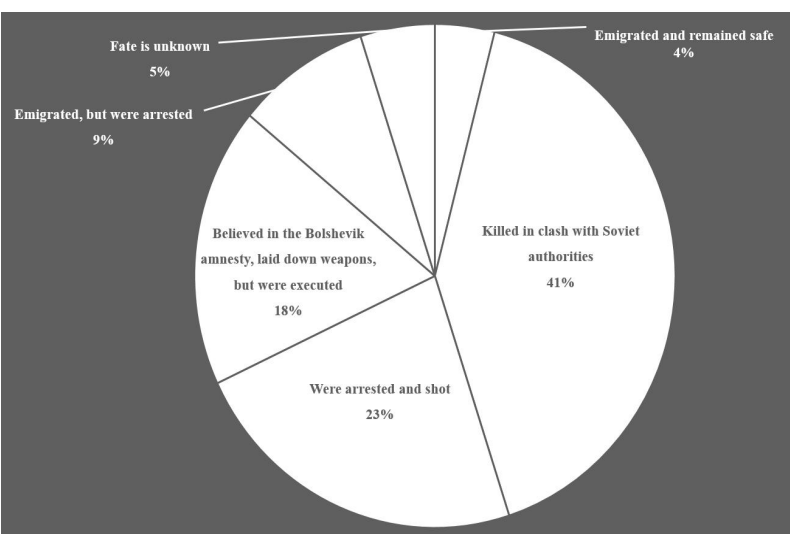

In our view, the political orientation of the otamans is often ambivalent in nature and is difficult to prosecute. Thus, the political platform of three of the 22 rebel peasants leaders cannot be properly established due to lack of relevant information; at least four otamans have moved from bolshevism to idea of independence of Ukraine; the political orientation of the rest (with some reservations) was a synthesis of nominally anarchic and national-independent ideas.

Conclusions. As we can see, prosopography allows us to establish some patterns that are «elusive» at first glance, but this approach ignores the unique experience of historical actors. Thus, our analysis was limited only by the fact of participation of leaders of the rebel movement in World War I, but, for example, Py'ly'p Xmara was a complete Cross of St. George's gentleman, and Ivan Savchenko-Nagirny'j, who was serving at the headquarters, probably lacked real combat experience.

So the image of the average rebel otaman in the Middle Dnipro region was was like that: this is a 26.7 year old man; in $95.5 \%$ of cases - a local who in $72.7 \%$ of cases came from the same county where he fought insurgency; his profession is in $40 \%$ of cases a rural teacher and only 4-5\% - a professional military; in $84.2 \%$ of cases, they are veterans of the First World War, half of whom were officers or non-commissioned officers; most of them began insurgency in the spring or fall of 1919, and ceased during March 1921 - December 1922. The rebellious struggle of the average otaman in the Middle Dnipro region lasted 29.4 months, which is almost 2.5 years. After the cessation of the fight, $14 \%$ of the otamans found themselves in exile. The deaths of almost all the otamans were violent - death in battle, death, imprisonment, or Gulag prison camps.

It can be assumed that the use of prosopographic methods for ordinary insurgents will also reveal new patterns and trends, but because of their high fluidity, frequent rotations, and high data fragmentation, it is objectively impossible to do so.

\section{Bibliography:}

1. Війна з державою, чи за державу? Селянський повстанський рух в Україні 1917 - 1921 рр. / під заг. ред. В. Лободаєва. Харків, 2017. 399 с.

2. Ганжа О. Українське селянство в період становлення тоталітарного режиму $(1917$ - 1927 рр.). Київ : Ін-т історії України НАНУ, 2000. 208 с.

3. Героїзм і трагедія Холодного Яру / за ред. Р. Коваля. Київ : Поліфаст, 1996. 316 с.

4. Гриценко А. П. Політичні сили у боротьбі за владу в Україні: рік 1919 й. Київ : Ін-т історії України, 1996. 81 с. 5. Гриценко А. П. Політичні сили у боротьбі за владу в Україні: рік 1919 й. Київ : Ін-т історії України, 1997. 94 с. 6. Демартино А. П. Повстанський рух в Середньому Подніпров'ї України (1920-ті роки): дисертація канд. іст. наук. Київ, 2015. 259 с.

7. Захарченко П., Земзюліна Н., Нестеров О. У поході за волею (селянсько-повстанський рух на Правобережній Україні у 1919 р.). Київ : ЗАТ «Нічлава», 2000. 175 с.

8. Коваль Р. М. Отамани Гайдамацького краю. 33 біографії. Київ : Правда Ярославичів, 1998. 616 с.

9. Коваль Р. М. Повернення отаманів Гайдамацького краю. Київ : «Діокор», 2001. 320 с.

10. Лютий-Лютенко Іван Макарович. Енцииклопедія історії 
Украӥни в 10 m. Том 6 Ла-Мі / гол. редкол. В. А. Смолій. Київ : Наук. думка, 2009 С. 397.

11. Митрофаненко Ю. Українська отаманщина 1918 1919 рр. Кіровоград : Імекс-ЛТД, 2016. 238 с.

12. Петрова М. С. Просопография. Теория и методология исторической науки. Терминологический словарь / отв. ред. А. О. Чубарьян. Москва : Аквилон, 2014. С. 417-419.

13. Реабілітовані історією. Черкаська область / гол. редкол. В. А. Смолій. Книга десята. Черкаси, «ІнтролігаТОР», 2017. $-640 \mathrm{c}$.

14. Ревегук В. За волю України. Нариси історії повстансько-партизанської боротьби на Полтавщині в 1917 - 1923 рр. Полтава, 2007. 285 с.

15. Савченко Г. П. Водяний Яків Михайлович. Енииклопедія історії Украӥни в $10 \mathrm{~m}$. Том 1 А-В / гол. редкол. В. А. Смолій. Київ : Наук. думка, 2005 С. 592.

16. Савченко Г. П. Гризло Семен Григорович. Енциклопедія історї̈ України в $10 \mathrm{~m}$. Том 2 Г-Д/ гол. редкол. В. А. Смолій. Київ : Наук. думка, 2005 С. 202.

17. Щербатюк В. М. Селянський повстанський рух в Україні 1917 - 1921 років: українська історіографія. Київ : Наук. думка, 2012. 527 с.

\section{References:}

1. War with the state, or for the state? Peasant rebellion movement in Ukraine, 1917 - 1921 pp. (2017). Ed. by V. Lobodaev. - Kharkiv (in Ukr.)

2. Ganzha, O. (2000). The Ukrainian peasantry during the formation of the totalitarian regime $(1917$ - 1927). Kyiv (in Ukr.)

3. Heroism and Tragedy of the Xolodny ${ }^{\circ} \mathrm{j}$ Yar (the Cold Ravine) (1996). (Ed.) R. Kovaly. Kyiv (in Ukr.)

4. Gritsenko, A. (1996). Political forces in the struggle for power in Ukraine: the year 1919. Kyiv (in Ukr.)

5. Gritsenko, A. (1997). Political forces in the struggle for power in Ukraine: the year 1920. Kyiv (in Ukr.)

6. Demartino, A. (2015). Insurgent Movement in the Middle Dnieper Ukraine (1920's). PhD thesis. Kyiv (in Ukr.)

7. Zakharchenko, P., Zemzulina, N. \& Nesterov O. (2000). In the campaign of freedom (peasant-insurgent movement in Right-Bank Ukraine in 1919). Kyiv (in Ukr.)

8. Koval R. (1998). Otamans of the Haidamak Land. 33 biographies. - Kyiv (in Ukr.)

9. Koval, R. (2001). The Return of the Otamans of the Haidamak Land. Kyiv (in Ukr.)

10. Lyuty“j-Lyutenko Ivan Makarovy'ch (2009). Encyclopedia of the history of Ukraine in $10 \mathrm{vol}$. Vol. 6. (Ed.) V. Smolii. P. 397. Kyiv (in Ukr.)

11. Mitrofanenko, Yu. (2016). Ukrainian otamanshchyna, 1918 - 1919. Kirovograd. (in Ukr.)

12. Petrova, M. (2014). Prosopography. Theory and methodology of historical science. Glossary. (Ed.) A. Chubaryan. Moscow 2014, 417-419. (in Rus.)

13. Rehabilitated by history (2017). Cherkasy district. Vol. 10. (Ed.) V. Smolii. - Cherkasy (in Ukr.)

14. Reveguk, V. (2007). For the will of Ukraine. Essays on the history of the rebel-guerrilla struggle in Poltava in 1917 - 1923. Poltava (in Ukr.)

15. Savchenko, H. Vodyany`j Yakiv My‘xajlovy‘ch. Encyclopedia of the history of Ukraine in $10 \mathrm{vol}$. Vol. 1. (Ed.) V. Smolii. P. 592. Kyiv (in Ukr.)

16. Savchenko, H. Gry'zlo Semen Gry'gorovy'ch. Encyclopedia of the history of Ukraine in $10 \mathrm{vol}$. Vol. 2. (Ed.) V. Smolii. P. 202. Kyiv (in Ukr.)

17. Shcherbatiuk, V. (2012). Peasant rebel movement in Ukraine 1917 - 1921: Ukrainian historiography. Kyiv (in Ukr.)

\section{О. Компанієць, А. Морозов}

\section{КОЛЕКТИВНАБІОГРАФІЯПРОВІДНИКІВ СЕЛЯНСЬКОГОПОВСТАНСЬКОГО РУХУНА СЕРЕДНІЙ НАДДНІПЯЯНИНІ (1918-1920-ТІРР.)}

Постановка проблеми. Для вітчизняної історіографії доби незалежності тема селянського повстанського руху стала настільки популярною, щзо маємо досить підстав, аби виокремити ї̈ окремим напрямом студій з історії Украӥнської революиії 1917 - 1921 рр. Нараховуючи сотні бібліографічних позицій, «повстанська» проблематика може видатися вже значною мірою вичерпаною, однак відхід від популярних описових $i$ узагальнювальних методів на користь вузькоспеціальних є перспективним навіть стосовно, здавалося б, добре вивчених питань.

Метою публікації $\epsilon$ виявлення засобами «колективних біографій» раніше невідомих закономірностей $і$ тендениій, що мали місце в середовищі провідників селянського повстанського руху в Середньому Подніпров '̈ в 1918 - на початку 1920-х pp.

Результати і висновки. Об'єктами просопографічного аналізу стали біографії 22 провідників повстанського руху: Бабенка Трохима Івановича, Водяного Якова Михайловича, Гладченка Трифона Федоровича, Голика-Залізняка Мефодія Фокича, Гризла Семена Григоровича, Гупала Дениса Мусійовича, Дерешука Петра Кузьмовича, Деркача Івана Тимофійовича, Завгороднього Іларіона Захаровича, Кваші Василя Мироновича, Келеберди Панаса Дмитровича, КібияБондаренка Миколи Степановича, Лютого-Лютенка Івана Макаровича, Нестеренка Герасима Онуфрійовича, Петренка Івана, Савченка (СавченкаНагірного) Івана Григоровича, Філоненка Семена Дмитровича, Хмари Пилипа Панасовича, Цвітковського Дмитра, Чучупака Василя Степановича, Чучупака Олекси Степановича, Чучупака Петра Степановича.

Критеріями створення колективного портрету повстанських отаманів стали такі моменти: місие народження, вік, освіта, професія, наявність військового досвіду (зокрема, участь у Першій світовій війні), час початку $i$ завершення повстанської боротьби, політична орієнтація $i$ подальша доля.

Авторам вдалося встановити, щзо образ середньостатистичного селянського повстанського отамана на Середньому Подніпров'ї був таким: ие чоловік віком 26,7 років; у 95,5\% випадках - місиевий житель, який у 72,7 \% випадків походив з того ж повіту, де й вів повстанську боротьбу; його професія у 40 \% випадків - сільський вчитель $і$ лише у 4-5 \% професійний військовий; у 84,2 \% випадків - ие ветерани Першої світової війни, половина з яких була обер-, або унтерофіцерами; більшість з них почала повстанську боротьбу навесні, або восени 1919 р., а припинила протягом березня 1921 р. - грудня 1922 р. Повстанська боротьба середньостатистичного отамана на Середньому Подніпров'”̈ тривала 29,4 місяиі, тобто майже 2,5 роки. Після припинення боротьби $14 \%$ отаманів опинялися на еміграції. Смерть майже всіх отаманів була насильницькою: загибель в бою, страта, смерть у в'язнииі або таборах. 
Можна припустити, що застосування просопографічних методів до рядових повстанців також дозволить виявити нові закономірності й тенденції, проте через їх високу плинність, часті ротації, високу фрагментарність даних це зробити об 'єктивно складно.

Ключові слова: колективна біографія, колективний портрет, просопографічний аналіз, селянський повстанський рух, отамани, отаманщиина, Середня Наддніпрянщчина, Українська національна революиія 1917 - 1921 рр.

UDC 94(477:4-11):332.2.01]"18/19"(045)

DOI: $10.31651 / 2413-8142-2019-22-24-30$

S. Kornovenko

Doctor of Historical Sciences, Professor of the Department of Intellectual Property and Civil Law Disciplines of the Bohdan Khmelnytsky National University of Cherkasy ORCID: https://orcid.org/0000-0002-6268-2321

Y. Pasichna

$P h D$ in History, the I category specialist at the PhD department of the Bohdan Khmelnytsky National University of Cherkasy ORCID: https://orcid.org/0000-0002-7357-7623

\section{EASTERN EUROPEAN AGRARIANISM. UKRAINIAN INTELLECTUAL SPACE IN THE LATE $19^{\text {TH }}$ AND EARLY $20^{\text {TH }}$ CENTURIES}

Based on the analysis of a wide range of sources, the article focuses on the reasons for the emergence of Eastern European agrarianism, and understanding of the "Eastern European agrarianism" concept in a broad and narrow sense. Considering the spread area of Eastern European agrarianism on the basis of territorial character and peculiarities of socioeconomic and socio-political development of Eastern European countries, there are grounds to distinguish its variants: Polish, Bulgarian, Czechoslovakian, Romanian, Ukrainian, etc. Based on the analysis of the Ukrainian intellectual space in the late $19^{\text {th }}$ and early $20^{\text {th }}$ centuries, it is reasonable to assume that there were the ideas of Eastern European agrarianism presented by its Ukrainian variant in it. In particular, it affirmed a peasant-centric view of Ukrainianness, the peasant character of the Ukrainian nation, the separateness of city and countryside, urban and rural worldviews and ways of being. The identification of such concepts as "Ukrainian peasantry", "Ukrainian nation", and "Ukrainian people" was considered axiomatic in the views of the representatives of the Ukrainian intellectual space in the late $19^{\text {th }}$ and early $20^{\text {th }}$ centuries. The political future of the Ukrainian statehood was closely linked to the peasantry.

Keywords: Eastern European agrarianism, Ukrainian agrarianism, Ukrainian intellectual space, Ukrainian peasantry, M. Hrushevsky, P. Skoropadsky, V. Lypynsky.

Problem statement. The period of the late $19^{\text {th }}$ and early $20^{\text {th }}$ centuries is unique both in the life of Europe in general and of Eastern Europe in particular. In large part, it is the time of "awakening" of Eastern European nations, which would appear on the wreckage of continental empires in the early $20^{\text {th }}$ century. A characteristic feature of the "awakening" was the formation of ideologies of Eastern European nations. Eastern European agrarianism

* The article is written in accordance with the state budget theme "Ukrainian Revolution (1917-1921 gg.): The peasant factor" (state registration number 0118U003864). became one of them in the late $19^{\text {th }}$ and early $20^{\text {th }}$ centuries. Its ideology spread to Poland, Bulgaria, Romania, Czechia and Slovakia (later Czechoslovakia), Ukraine.

In our opinion, the reasons for the emergence of agrarianism in general (Germany - G. Roland, A. Scheffle; in France - the concept of J. Melin) and Eastern European one in particular were as follows. First, the conflict between industrial and agrarian civilizations, which clearly began to manifest itself in the late $19^{\text {th }}$ and early $20^{\text {th }}$ centuries in the conditions of modernization of agrarian-industrial countries and economies and their transformation into industrial-agrarian or approximated to them with corresponding transformation of values. One of the examples is the socio-economic and sociopolitical models of the Russian and Austro-Hungarian empires, which had similar modernizations in the late $19^{\text {th }}$ and early $20^{\text {th }}$ centuries. The modernization processes had an influence in Czechia, Slovakia, Poland, Ukraine, etc. being the future independent entities of international law, the countries representing Eastern European agrarianism, which were a part of the Romanov and Habsburg empires, respectively, at that time. We believe that the advancement of the industrial civilization of the Western sample to the Eastern European agrarian space provoked a defensive reaction of the peasantry, the part of the largest social strata of Eastern European countries. It became Eastern European agrarianism represented by Polish, Bulgarian, Czechoslovakian, Romanian, Ukrainian and other variants.

Second, the development of political culture of agrarian nations, which in that time, were Polish, Bulgarian, Czechoslovakian, Romanian, Ukrainian, and so on. The political cultures of Polish, Bulgarian, Czechoslovakian, Romanian, Ukrainian, etc. peasants experienced the modernization of values. In our opinion, there was a significant socio-cultural shift in the collective and individual political culture and consciousness of the peasants in the form of the transition from an indifferent political culture and consciousness to an activist one.

Third, the objective laws of the development of the agrarian civilization itself, the formation of a qualitatively different peasantry in it. In Ukraine, it was the peasantideoman, the active subject of history [1]. In the early $20^{\text {th }}$ century, the Ukrainian peasantry was qualitatively different from both the urban proletariat and the peasantry of previous centuries, formed under fundamentally new conditions of post-serfdom reality. The qualitative difference was the absence of serfdom not only as a legal status. First of all, it is the absence of serfdom as a way of being, keeping an economy, thinking style, etc. It was a generation brought up under the conditions of agricultural capitalization, industrialization, and transformation of the rural community considered to be the modernization of the late $19^{\text {th }}$ and early $20^{\text {th }}$ centuries in the Russian Empire. The peasants gradually became aware of themselves as a separate community of the socio-cultural imperial space of that time. The unifying value was the "Idea of Land", its distribution on just principles in their understanding. Our considerations are in line with the position of other modern researchers [2]. We support A. Gordon's reasoning that the abolition of serfdom turned the peasant into a "rational agent" in the interpretation of classical political economy and common sense. The psychology of the peasant became more resilient to those new phenomena that actively penetrated peasant 